\begin{tabular}{|l|l|l|}
\hline \multicolumn{2}{|c|}{ PublisherInfo } \\
\hline \hline PublisherName & $:$ & BioMed Central \\
\hline \hline PublisherLocation & $:$ & London \\
\hline \hline PublisherImprintName & $:$ & BioMed Central \\
\hline \hline
\end{tabular}

\title{
Proteomics of radiation resistance
}

\begin{tabular}{|l|l|l||}
\hline \multicolumn{2}{|c|}{ ArticleInfo } \\
\hline \hline ArticleID & $:$ & 4310 \\
\hline \hline ArticleDOI & $:$ & $10.1186 /$ gb-2002-3-12-reports0061 \\
\hline \hline ArticleCitationID & $:$ & reports0061 \\
\hline \hline ArticleSequenceNumber & $:$ & 33 \\
\hline \hline ArticleCategory & $:$ & Paper report \\
\hline \hline ArticleFirstPage & $:$ & 1 \\
\hline \hline ArticleLastPage & $:$ & 3 \\
\hline \hline & & RegistrationDate : 2002-9-30 \\
ArticleHistory & $:$ & Received $\quad: 2002-9-30$ \\
& $:$ OnlineDate \\
\hline \hline ArticleCopyright & $:$ & BioMed Central Ltd2002-11-27 \\
\hline \hline ArticleGrants & $:$ & \\
\hline \hline
\end{tabular}




\begin{tabular}{|l|l|l|}
\hline ArticleContext & $:$ & 13059331212 \\
\hline
\end{tabular}

\section{Wim D'Haeze}

\section{Summary}

An extensive proteome analysis will help understand how $D$. radioduranssurvives under extreme conditions

\section{Significance and context}

Deinococcus radiodurans, a Gram-negative, non-motile, red-pigmented, non-pathogenic bacterium, was first isolated in 1956 from a can of ground beef that had been radiation-sterilized but had spoiled nonetheless. Probably because $D$. radioduranshas the capacity to efficiently repair radiation breakage to its DNA, it can endure 1.5 million rad, a radiation dose 3,000 times higher than would kill most other organisms - from microbes to humans. Moreover, it can withstand both acute and chronic exposure to high levels of radiation. $D$. radioduransis believed to be suitable for bioremediation programs, to clean up mixed-waste sites contaminated with toxic chemicals as well as radiation. Research is ongoing to alter the genetic content of $D$. radioduransin order to detoxify the most common chemical contaminants at such sites. It is proposed that the underlying mechanism for its exceptional resistance to radiation may be a combination of a complex array of interacting proteins and many subtle structural peculiarities of proteins and DNA. Lipton et al. have developed a new method of efficient high-throughput identification of peptides by mass spectroscopy using accurate mass tags (AMTs) for each of the proteins expressed by the given organism. Proteins are digested to yield a mixture of polypeptides that are analyzed to create a collection of AMTs, which in turn serve as biomarkers for the parent protein. This new method was applied to analyze the $D$. radioduransproteome.

\section{Key results}

In the current analysis, the 3,116 predicted open reading frames (ORFs) were taken into account. The measurements identified 6,997 AMTs with high confidence, corresponding to 1,910 ORFs, covering about $61 \%$ of the predicted ORFs. Proteins were prepared from $D$. radioduranscultures harvested at different time points (mid log phase or late log phase) or grown under different conditions, including defined media, rich media, heat or cold shock, hydrogen peroxide shock and toluene shock. Lipton et al. found that two classes of stress proteins with a role in detoxification processes are catalases and superoxide dismutases. The RecA protein is pivotal for the recombinational repair of double-strand 
breaks in DNA that are caused by radiation. Five different RecA AMTs covering $34 \%$ of the sequence were identified in cells exposed to radiation.

\section{Links}

The entire genome sequence of $D$. radioduranscan be accessed at The\%20Institute\%20for\%20Genomic\%20Research:\%20Deinococcus\%20radioduransR1 website and at the NCBI:\%20summary\%20sequence page.

\section{Reporter's comments}

Lipton et al. have developed a new high-throughput technique to analyze the proteome of virtually any organism with a high efficiency and precision. The technique has been applied to the proteome of $D$. radioduransin the first instance. The analysis of the production of an extended set of proteins under different stress conditions provides insights into the molecular mechanisms by which this bacterium copes with extreme stress such as severe radiation, and thus how it can be engineered to be used in bioremediation programs. The technique can be applied to obtain insights into the eukaryote proteomes, such as that of humans, which will be accessible for study in the near future.

\section{Table of links}

Proceedings $\% 200 f \% 20$ the $\% 20$ National $\% 20$ Academy $\% 200 f \% 20$ Sciences $\% 20 o f \% 20$ the $\% 20$ United $\% 20$ States $\% 20$ The\%20Institute\%20for\%20Genomic\%20Research:\%20Deinococcus\%20radioduransR1

NCBI:\%20summary\%20sequence

\section{References}

1. Lipton MS, Pasa-Tolic L, Anderson GA, Anderson DJ, Auberry DL, Battista JR, Daly MJ, Fredrickson J, Hixson KK, Kostandarithes H, et al: Global analysis of the Deinococcus radioduransproteome by using accurate mass tags. Proc Natl Acad Sci USA. 2002, 99: 11049-11054.

This PDF file was created after publication. 